\title{
ФАКТОРИ ЗАБЕЗПЕЧЕННЯ ЕФЕКТИВНОСТІ ЗАМКНУТОЇ МЕДИЧНОЇ ОСВІТИ В СУЧАСНИХ УМОВАХ: НЕФОРМАЛЬНІСТЬ, ТРАНСДИСЦИПЛІНАРНІСТЬ І БЕЗПЕРЕРВНІСТЬ
}

\author{
Ю. В. Вороненко, О. П. Мінцер \\ Національна медична академія післядипломної освіти імені П. Л. Шупика
}

\begin{abstract}
Розглянуто фрактори, що забезпечують якість та ефективність сучасного безперервного профресійного розвитку лікарів і провізорів. Серед значної кількості фракторів виділено трансдисциплінарність, безперервність, органічне поєднання фрормальної, неформальної та інформальної освіти. Дослідження було спрямовано на обґрунтування технології фоомування індивідуальної освітньої траєкторії під час безперервного профресійного розвитку. З'ясовано, що створення сучасної системи транссеру знань у медицині можливо за умови врахування необхідності забезпечення високої якості навчання лікарів і провізорів, орієнтованого на підготовку особистості, інтенсивне впровадження трансдисциплінарності навчання. Основою сучасного набуття знань, навиків і інших компетентностей у післядипломній медичній освіті та безперервному професійному розвитку лікарів і провізорів запропоновано введення індивідуальної освітньої траєкторії, що базується на трьох складових - максимальній цифрровізації, професіональному портфоліо та контент - аналізі.
\end{abstract}

Ключові слова: моделі медичної освіти, цифрровізація, онтологія знань, індивідуальна освітня траєкторія, принцип фрормалізації, трансдисциплінарність, модулі навчання, контент - аналіз.

\section{FACTORS OF PROVIDING THE EFFICIENCY OF A CLOSED MEDICAL EDUCATION IN THE MODERN CONDITIONS: INFORMALITY, TRANSDISCIPLINARITY AND CONTINUITY}

\author{
Yu. V. Voronenko, O. P. Mintser \\ Shupyk National Medical Academy of Postgraduate Education
}

\begin{abstract}
Background. The factors that ensure the quality and effectiveness of modern continuous professional development for doctors and physicians are considered. Among the many factors are transdisciplinarity, continuity, organic combination of formal, non-formal and informal education. The purpose of the study was to substantiate the technology of formation of individual educational trajectory during the continuous professional development.

Materials and methods. Results. Medical education has fundamentally changed and will continue to change in accordance with scientific achievements and the needs of society. In the reform of medical education more and more places are occupied by information technologies, distance learning, platform learning. Learners need perfect learning and better experience in functioning and decision making. The creation of an individual educational trajectory is crucial. The main principles in the formation of the trajectory are the provision of digitization, as well as the use of content analysis. Possibilities of application of ontological models are considered for construction of an estimation cluster.

Conclusion. It is concluded that the creation of a modern system of knowledge transfer in medicine is possible, taking into account the need to ensure the high quality of training of doctors and pharmacists, training focused on personality training, intensive implementation of transdisciplinary training of specialists. The basis of modern training of doctors in postgraduate medical education and continuous professional development of doctors and pharmacists is proposed to introduce individual educational technologies, based on three components - maximum digitalization, professional portfolio and content - analysis.
\end{abstract}

Key words: models of medical education, digitization, ontology of knowledge, individual educational trajectory, principle of formalization, transdisciplinarity, modules of training, content - analysis. 


\title{
ФАКТОРЫ ОБЕСПЕЧЕНИЯ ЭФФЕКТИВНОСТИ ЗАМКНУТОГО МЕДИЦИНСКОГО ОБРАЗОВАНИЯ В СОВРЕМЕННЫХ УСЛОВИЯХ: НЕФОРМАЛЬНОСТЬ, ТРАНСДИСЦИПЛИНАРНОСТЬ И НЕПРЕРЫВНОСТЬ
}

\author{
Ю. В. Вороненко, О. П. Минцер
}

Национальная медицинская академия последипломного образования имени П. Л. Шупика

Рассмотрены фракторы, обеспечивающие качество и эффективность современного непрерывного просрессионального развития врачей и провизоров. Среди большого количества фракторов выделены трансдисциплинарность, непрерывность, органическое сочетание формального, неформального и информального образования. Исследование было направлено на обоснование технологии фрормирования индивидуальной образовательной траектории при непрерывном профессиональном развитии. Сделан вывод о том, что создание современной системы трансфера знаний в медицине возможно при условии принятия во внимание необходимости обеспечения высокого качества обучения врачей и провизоров, ориентированного на подготовку личности, интенсивного внедрения трансдисциплинарной подготовки специалистов. Основой современного приобретения знаний, навыков и других компетентностей в последипломном медицинском образовании и непрерывном профессиональном развитии врачей и провизоров предложено введение индивидуальной образовательной траектории, основанной на трех составляющих - максимальной цифрровизации, профессиональном порторолио и контент - анализе.

Ключевые слова: модели медицинского образования, цифровизация, онтология знаний, индивидуальная образовательная траектория, принцип фрормализации, трансдисциплинарнисть, модули обучения, контент - анализ. 
Вступ. Класична модель сучасної вищої освіти забезпечує в ній центральне місце особі, яка навчається [1]. Відповідно, для того, хто навчається, має існувати можливість знайти найзручніші для себе відповіді на запитання: що вивчати, коли та де вчитися, а також у яких викладачів отримувати знання та компетентності. Вони повинні відповідати не тільки певним очікуванням, але й прийнятим нормативам.

Процес такої освіти, зазвичай, не контролюється централізованою організацією. Суб’єкт навчання може вільно поєднувати звичайне контактне навчання з електронним або віртуальним навчанням, професійними школами, іншими можливостями, такими як стажування, тренінги, майстер-класи тощо. Подібний формат освіти (в деяких дослідженнях названий відкритим [2]) надає великі переваги одержувачу знань, але абсолютно не забезпечує оптимальності навчального шляху, суттєво зменшує ймовірність отримання трансдисциплінарної освіти, підготовку особистості.

Проте основним питанням організації освіти, в першу чергу, медичної, є її системність, логіка питомої ваги відкритості, взаємодія системи з навколишнім оточенням.

Як відомо, система може бути визначена як набір певним чином організованих та взаємопов' язаних і взаємозалежних структур, компонентів та інших елементів, створених для виконання певної діяльності або для вирішення проблеми. В раках загальної теорії виділяють замкнені та відкриті системи. Замкнуті навчальні системи практично не взаємодіють із навколишнім середовищем і не схильні до впливу її оточення. В той же час відкриті системи - забезпечують постійний обмін інформацією з зовнішнім середовищем, допускають можливості взаємодії з іншими структурами та системами. Слід підкреслити, що практично всі сучасні освітні організації працюють навколо перспективи відкритих систем. Трансформація системи медичної освіти та, в першу чергу, післядипломної її частини, швидко рухається саме в цьому напряму, проте постійне стикається з безліччю проблем. Останні пов'язані з відсутність єдиного освітнього простору, єдиних критеріїв оцінювання якості освіти, драматичною зміною навчальних парадигм, обумовлених новими інформаційними технологіями. До того ж, більшість країн зіткнулися з проблемою нестачі викладачів, які знаються на сучасних принципах і методах передавання знань. Щоб стимулювати створення «нового обличчя» освітньої сфери ведуться нескінчені дискусії щодо найкращих стратегій. Запропоновано створення економічних незалежних навчальних спільнот, що повинні нести колегіальну відповідальність за якість освіти [8].

Основні труднощі пов'язані з тим, як не виходячи за рамки чинного законодавства, зробити вищу школу привабливішою для бажаючих навчатися. Одним із способів зробити це являється створення відкритої системи освіти та надання суб’єктам навчання можливості досягнення освітніх цілей шляхом пошуку отримання частини навчання в іншому закладі вищої освіти (3ВО) або шляхом поєднання роботи суб'єкту навчання з програмою навчання (дуальна освіта). Інші напрями пов'язано 3 органічним поєднанням формального, неформального та інформального видів навчання. В усіх цих випадках 3ВО стають невід'ємною частиною навколишнього освітнього простору, в якому вони знаходяться. Це, безумовно, позитивний фактор. Але в результаті виникає необхідність в актуальній та достовірній інформації про якість освітніх програм, оцінювання перспективності навчання тощо. Стратегічним питанням для суб'єктів навчання стають проблеми вибору навчального контенту, оцінювання своїх можливостей, обгрунтування шляхів створення власної особистості. В той час для закладів вищої освіти, що в цілому сприймають процес відкритого навчання, виникають проблеми збереження власного «обличчя», традицій тощо.

Мета роботи: запропонувати технології формування індивідуальної освітньої траєкторії.

Результати та їх обговорення. Загально відомо, що медична освіта принципово змінилася та буде продовжувати змінюватися відповідно до наукових досягнень і потреб суспільства. У реформі медичної освіти все більше місця займають інформаційні технології, дистанційне навчання, платформне навчання. Однак, ентузіазм щодо реформи повинен стримуватися більш зваженим підходом, із тим щоб уникнути ненавмисних наслідків [3]. За загальною думкою, для задоволення моделі навчання сучасних студентів-медиків і лікарів, під час післядипломної освіти, педагогічні підходи не можуть бути просто модифіковані шляхом змішування лекційних і не лекційних форматів [4]. Абсолютно принципово, що стандарти змісту освіти повинні залишатися константними (відповідно часу навчання); педагоги не можуть іти на компроміс стосовно матеріалу, що повинен бути вивчений [5]. Суб'єкти навчання мають потребу 
в досконалому навчанні та набутті кращого досвіду функціонування й прийняття рішень перед обличчям неминучої невизначеності в житті та медичній практиці [3].

Вирішального значення набуває, з нашої точки зору, створення індивідуальної освітньої траєкторії. Вона повинна мати не тільки всі класичні модулі сучасної освіти - знанієвий, компетентністний, модуль навиків, оціночний та, нарешті, персонально-орієнтований. Украй важливим стає й урахування форматів неформальної освіти, а також включення логіки трансдисциплінарності в навчання та безперервний професійний розвиток лікарів і провізорів.

Головним принципом при формуванні траєкторії $€$ забезпечення цифровізації. Вважаємо, що для цього слід широко використовувати онтологію знань, надійне фіксування потрібних характеристик (логіка формалізації), а також принцип статистичної значущості питань, що цікавлять суб’єкта навчання.

Пропонується також використовувати контент аналіз. Для цього виявляються розділи навчального матеріалу, що користуються підвищеним попитом, оцінюється текст як індикатор окремих сторін

\section{Література.}

1. Harden R. M. Ten key features of the future medical school — not an impossible dream / Harden R. M. // Medical Teacher. — 2018. — T. 40, № 10. — P. 10101015.

2. Open Education: International Perspectives in Higher Education, 1st ed. (Open Book Publishers) / Blessinger P., Bliss T. J. — UK: Cambridge, 2016. — 356 p.

3. Buja L. M. Medical education today: all that glitters is gold / Buja L. M. // BMC Med. Educ. — 2019. № 19. - P. 110.

4. The effectiveness of blended learning in health professions: systematic review and meta-analysis / Liu Q., Peng W., Zhang F. et al. // J Med Internet Res. 2016. - Vol. 18, № 1. - e2.

5. Twenge J. M. Generational changes and their impact in the classroom: teaching generation me // Med Educ. 2009. — № 43. — 398-405.

6. Mayring Ph. Qualitative Content Analysis: theoretical foundation, basic procedures and software solution. - Klagenfurt: Creative Commons - AttributionNoncommercial-No Derivative Works, 2014. — 143 p.

7. Yin R. K. Qualitative research from start to finish. - New York: Guilford Press, 2011. - 386 p. досліджуваного об’ єкту, досліджується сприйняття контенту суб'єктами навчання. Іншими словами, здійснюються процедури, що за влучним визначенням ряду соціологів [6, 7] можна було б назвати «текстуальним кодуванням».

Для побудови оціночного кластеру розглядаються можливості застосування онтологічних моделей, що включають кількісні характеристики повноти та достатності отриманих знань за окремими темами, модулями та розділами навчальної дисципліни.

Висновки. 1. Трансформація системи трансферу знань у медицині важлива та можлива, але реалізація відповідних процесів повинна враховувати необхідність забезпечення високої якості підготовки суб’ єктів навчання, особистісного навчання, інтенсивного впровадження трансдисциплінарної підготовки спеціалістів.

2. Основою сучасного навчання в післядипломній медичній освіті та безперервному професійному розвитку лікарів і провізорів запропоновано вважати індивідуальну освітню траєкторію, що базується на трьох складових — максимальній цифровізації, професіональному портфоліо та контент - аналізі.

\section{References.}

1. Harden, R. M. (2018). Ten key features of the future medical school — not an impossible dream. Medical Teacher., 40:10, 1010-15.

2. Blessinger, P., Bliss, T. J. (2016). Open Education: International Perspectives in Higher Education, 1st ed. Open Book Publishers. Cambridge, UK.

3. Buja, L. M. (2019). Medical education today: all that glitters is gold. BMC Med. Educ., 19, 110.

4. Liu, Q., Peng, W., Zhang, F. et al. (2016). The effectiveness of blended learning in health professions: systematic review and meta-analysis. J Med Internet Res., 18:1, e2.

5. Twenge, J. M. (2009). Generational changes and their impact in the classroom: teaching generation me. Med Educ., 43, 398-405.

6. Mayring, Ph. (2014). Qualitative Content Analysis: theoretical foundation, basic procedures and software solution. Klagenfurt.

7. Yin, R. K. (2011). Qualitative research from start to finish. New York: Guilford Press. 